\title{
Performance of Distance Learning Compared with Face to Face Learning
}

\author{
Karzan Wakil ${ }^{1}$, Aram Abdulfaraj ${ }^{2}$, Abbas Sadula ${ }^{3}$, Dashne Tofiq ${ }^{4}$, Lezan Nawzad $^{5}$ \\ ${ }^{1}$ Research Center, Sulaimani Polytechnic University, Kurdistan, Iraq \\ Email: karzanwakil@gmail.com \\ ${ }^{2}$ Institute of Training and Educational Developent, Sulaimani, Iraq \\ Email: Aram.faraj@gmail.com \\ ${ }^{3}$ Institute of Training and Educational Developent, Sulaimani, Iraq \\ Email: Abbas.sadula@gmail.com \\ ${ }^{4}$ Institute of Training and Educational Developent, Sulaimani, Iraq \\ Email: Dashne.tofiq@gmail.com, \\ ${ }^{5}$ National Institute of Technology, Iraq \\ Email: lezan82@gmail.com
}

(Received: January-2019; Reviewed: March-2019; Accepted: April-2019; Published: April-2019)

\begin{abstract}
This study aims to addresses the gap between the philosophy of distance learning and FTF learning among primary schools. Additionally, this research also aims to compare the student learning outcomes using distance and face-to-face (FTF) in statistics courses. To test the validity of the outcomes, we select three schools in Sulaimani city/ Iraq. The population of the research was selected in the seventh and tenth graders, two groups for each grade were determined for the research. For the FTF teaching method, direct lectures in the computer lab were presented to the students. While, for the distance learning method, the online course was introduced to via Skype. At the end of each teaching course, a text exam was performed for both groups. The results showed that students passing rate in the exam using FTF was $91 \%$ and $83 \%$ in Sarchya and Kareem Zand basic school respectively compared to only $67 \%$ for online classes in both schools in seventh graders. While for tenth grades in Bakrajo Industrial High School the passing rate for FTF was $81 \%$ and for virtual class $60 \%$. This result shows that the students who did not visit classroom performed poorer understanding rate compared to those who attended the class in FTF method.
\end{abstract}

Keywords: Distance Learning, Face to Face Leering, Educational Technology.

\section{INTRODUCTION}

Distance or online learning is becoming one of the most widely embraced ways of a delivery program for many education sectors. For example, in the United States, it is estimated that about 6 million individuals took at least one online course in 2015 (Allen \& Seaman, 2016). Previously, a number of distance programs have been aimed at primary and secondary school students. (Commission, Kerrey, \& Isakson,
2000; Hassel, Terrell, \& Impact, 2004), funding shortages, overcrowded brick and mortar facilities (Clark \& By, 2001), and exploration of alternative forms for education(Collins, 2001; Herring, 2004).

Schools, where all or most teaching and learning take place in online courses, are classified under a specific category called Virtual Schools (Watson, Murin, Vashaw, Gemin, \& Rapp, 2011). These schools use the advantages of online learning to create holistic 
school organizations (Dobrovolny et al., 2015). They differ from traditional schools, as students do not meet with teachers and other students in a physical space; most teaching, learning, and interaction occur in an online space (Berge, 2005; Moore \& Kearsley, 2011). Even in Some virtual schools, they allow the students to take all of their schoolings through the online organization known as primarily North American phenomenon (Barbour, 2009).

According to a study implemented by the United States Distance Learning Association (USDLA), online education and traditional classroom learning have no significant effect on student learning outcomes. The."(SCHOLLEY, 2001). Most of the researchers that evaluate the differences between online educations and conventional face-to-face education usually use the measurement of student attitudes and/or preferences (Alavi, Yoo, \& Vogel, 1997; Aragon, Johnson, \& Shaik, 2002; Caetano, Oliveira, Araújo, \& Rêgo, 2018; Estelami, 2017; Glenn, 2001; Johnson, Aragon, Shaik, \& PalmaRivas, 1999; Leszczyński et al., 2018; Ponzurick, France, \& Logar, 2000; Pratt \& Williamson-Leadley, 2017). On the other hand, other researchers have implemented direct measures of student's learning outcomes such as GPAs or exam grades in order to measure differences in the educational methods (Ajiboye, Bakare, Fatima, \& Shakira, 2018; Bidjerano, 2016; Graber, 2016; Hachey, Wladis, \& Conway, 2015; Johnson et al., 1999; Leasure, Davis, \& Thievon, 2000; Smeaton \& Keogh, 1999; Tucker, 2000; Tuckman, 2002). While another investigation pointed out that information technology could be an effective and beneficial tool in the education and learning process if aimed at specific learning goals. Besides, only few studies are found and skill development in online courses (Priluck, 2004).

Distance learning is a new type of learning process in Kurdistan Region-Iraq (KRI). However, some of the schools use technology for increasing the capability of learning, but still distance learning is newly introduced process. In recent works, our team presents the role of technology in the learning and teaching process in the primary and secondary schools in the KRI. Generally, we concluded that using technology is more effective for learning than traditional learning (Mohammed, Wakil, \& Nawroly, 2018; Nawzad, Rahim, \& Said, 2018; K Wakil, Muhamad, Sardar, \& Jalal, 2017; Karzan Wakil,
Nasraddin, \& Abdulrahan, 2018; Karzan Wakil, Omer, \& Omer, 2017; Karzan Wakil, Qaisar, \& Mohammed, 2017). However, there are several problems associated with the technology learning process in KRI such as: the capability of learning in the center of cities compared with outside cities; moving students from inside KRI to outside and returned them will have a bad effect on the learning process of the students, different styles from different types of schools in KRI, weather, economy, and so on. For these reasons, in this paper, we seek the effectiveness of distance learning compared with face to face learning through testing two groups of students in the Sulaimani city.

Many reviews about distance learning and face to face learning exist. The excellent systematic review for a comparison between distance learning and face to face learning proposed by Kathleen Mathieson, 2018 (Mathieson, 2010). Systematic research compared the group of students' achievement and satisfaction in statistic courses that have been taught using both online and FTF methods. Student achievements were generally similar between online and FTF methods, however, results on students' satisfaction were unsatisfied. However, many works implemented on distance learning such as (Chimpololo, 2010; Davis, 2017; Gürsul \& Keser, 2009; Helleve, 2012; Ni, 2013; Sultana \& Kamal, 2002), but In the following, we review most important relevant works.

Pratt and Williamson,2017 reports on a design-based research approach to developing a framework aimed at providing secondary students involved in online learning with the support they need to be successful. This framework has been informed by current theories and frameworks for best practice in distance and online education at both the higher education and school sectors. The paper will report on both the development of the framework and the results of evaluations of its effectiveness (Pratt \& Williamson-Leadley, 2017).

In another work Taylor and McNair, 2018 examined the foundational processes at three California virtual schools in traditional school districts. An analysis of the findings revealed that sites perceived the establishing founder, preliminary research, district support, teacher and staff selection, financial evaluation, and curriculum decisions as keys to the founding process. The analysis also led to surprising 
conclusions, including the need for virtual schools to constantly change and adapt the focus in the study of organizations over technology. The findings have implications for traditional districts starting virtual schools. The study also indicates that changes in policy could reduce the need for organizational adaptation among virtual schools in traditional school districts(Taylor \& McNair, 2018).

A new way for distance learning is mobile learning (m-learning) technologies in education which primarily demands that teachers' and students' adequacy and perceptions of such technology should be determined. Ozdamli and Uzunboylu, 2015 on their study compare teachers' and students' abilities and perceptions concerning m-learning. Research data for the analysis were obtained from a sample of 467 teachers and 1556 students from 32 schools that were surveyed in Northern Cyprus. Based on the results of this survey, it was concluded that teachers and students want to use m-learning in education. Their perceptions are positive but their m-learning adequacy levels are not sufficient (Ozdamli \& Uzunboylu, 2015).

A project program implemented in China named (DEPRS) between 2003 and 2007 designed to use distance learning programs to improve the quality of basic education especially in remote areas. The findings of the paper reveal that distance learnings have effectively raised the quality of education in a remote area of China rural areas via enriching and providing learning sources and also offering the teachers valuable and resourceful training courses to improve and alleviate their teaching skills. Furthermore, the students became more interested in learning and their performance was notably improving (McQuaide, 2009).

A study by Lewis et al., 2014 has examined the benefits and challenges of online learning program for at-risk high school students. The results showed that at-risk students find out the benefits and challenges of online learning is the same. However, students valued the opportunity to study at their own pace. this research also discussed that, with suitable support instructions, students who are at-risk for dropping out course and effectively overcome challenges and find success in an online learning programs (Lewis, Whiteside, \& Dikkers, 2014).

The education system has witnessed rapid change recently; the online system has entered many phases in the education sector such as online courses and programs and student enrolment system in every sector of education. Nowadays, online education became one of the important tools that could replace many tasks that have been done in face to face manner in the past years. However, researches about the student performance between face to face and the online system still challenging because of many reasons like lack of demographic and academic controls.

A study done by a group of researchers included over 5000 courses taught by 100 university members for a period of 10 academic terms in four-years university scale, this study performed to show differences in grade- based learning outcomes that could be featured to course format. The results of this study showed that there is little to no significant difference in grade-based student performance between face to face and online mode for courses that means both ays is applicable. (Cavanaugh \& Jacquemin, 2015).

However, in some researches, it was reported that FTF learning style and online courses have no significant effects on students' academic achievement in comparison to. A study conducted by Neuhauser (2010) revealed that there are no significant differences in test scores, assignments, participation grades, and final grades of the students using either FTF or distance online courses. Interestingly, in another study by Phillip and Cain (2015) which tested the delivering of course content using online teaching method instead of FTF method and revealed that instructors faced issues challenged their duties as teachers which related to their pedagogy, their classroom practices, and the power relations in the virtual classroom.

Above review parents that distance learning is a useful type of learning and solved many problems like budges, saving time, etc. Moreover, different techniques and different methods are used for increasing learning students' GPA as well. In the next section, we propose a methodology to implement distance learning in primary school and compared with FTF learning.

\section{METHOD}

With the aim of determining the effectiveness of distance learning compared with face to face learning, this research was conducted on two groups of students in three schools of Sulaimani city. The participating 
schools are; Sarchya Basic School, Karem Zad Basic School and Bakrajo Industrial High School with 232 students. The course was MS Word course taught in six weeks period time. After the teaching sessions, a testing method was used to evaluate the achievement and understanding of the students. The population of the research was selected in the seventh and tenth graders. Two groups for each grade were determined for the research. For the FTF teaching method, direct lectures in the computer lab were presented to the students. While, for the distance learning method, the online course was introduced to the students via Skype using the Fast link internet network during the sessions. At the end of the course, a text exam was performed for both groups and the results recorded as shown in Figure 1.

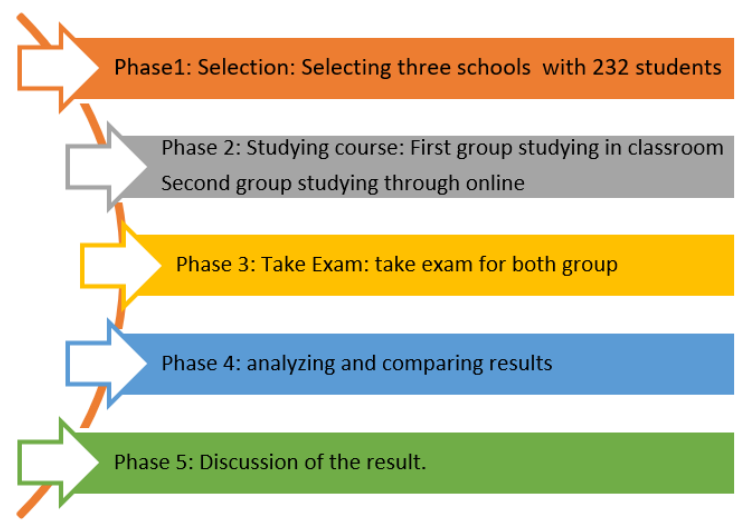

Figure 1: Course subjects introduced to the students for assessing distance and FTF learning methods.

\section{RESULT AND DISCUSSION}

This chapter presents the finding and outcomes of the effectiveness of distance learning compared with FTF method in MS word course by evaluating the students' achievement and understanding. For each method in each school two groups were allocated for the research one for distance learning and the other for FTF method. As mentioned in the previous section 232 students were participating in this study. For the FTF method, 112, 60 and 43 students and for distance learning method 6, 5, 5 in Sarchya basic school, Kareem Zand basic school and Bakrajo Industrial High School were involved respectively as shown in Table 1.
Table 1: Students numbers participated in each school in Sulaimania - City

\begin{tabular}{|c|c|c|c|}
\hline $\begin{array}{l}\text { School } \\
\text { Names }\end{array}$ & $\begin{array}{l}\text { Types of } \\
\text { Learning } \\
\text { Method }\end{array}$ & Grades & $\begin{array}{l}\text { Number of } \\
\text { Students }\end{array}$ \\
\hline Sarchya & FTF & \multirow[b]{2}{*}{ Seventh } & 112 \\
\hline $\begin{array}{l}\text { Basic } \\
\text { School }\end{array}$ & $\begin{array}{l}\text { Distance } \\
\text { learning }\end{array}$ & & 12 \\
\hline Kareem & FTF & \multirow[b]{2}{*}{ Seventh } & 60 \\
\hline $\begin{array}{c}\text { Zand Basic } \\
\text { School }\end{array}$ & $\begin{array}{l}\text { Distance } \\
\text { learning }\end{array}$ & & 12 \\
\hline \multirow{3}{*}{$\begin{array}{c}\text { Bakrajo } \\
\text { Industrial } \\
\text { High } \\
\text { School }\end{array}$} & FTF & \multirow[b]{2}{*}{ Tenth } & 43 \\
\hline & $\begin{array}{l}\text { Distance } \\
\text { learning }\end{array}$ & & 10 \\
\hline & & Total & $\begin{array}{l}232 \\
\text { students }\end{array}$ \\
\hline
\end{tabular}

After implementing the mentioned methodology in each school for six weeks, a testing exam was conducted for each group in class to evaluate the student's achievement and understanding. In this research, it was shown that most of the students desired the FTF method compared to the virtual class using a distance method for learning. For seventh graders, the results showed that students passing rate in the exam using FTF was $91 \%$ and $83 \%$ in Sarchya basic school and Kareem Zand basic school respectively compared to $67 \%$ for virtual classes in both schools. While for tenth grades in Bakrajo Industrial High School the passing rate for FTF was $81 \%$ and for virtual class $60 \%$ (Table 2).

Table 2: Student's passing rate for FTF and Distance learning methods

\begin{tabular}{|c|c|c|c|c|}
\hline $\begin{array}{l}\text { School } \\
\text { Names }\end{array}$ & $\begin{array}{l}\text { Types of } \\
\text { Learning } \\
\text { Method }\end{array}$ & Grades & $\begin{array}{l}\text { Number } \\
\text { of } \\
\text { Students }\end{array}$ & $\begin{array}{l}\text { Passing } \\
\text { rate }\end{array}$ \\
\hline \multirow{2}{*}{$\begin{array}{c}\text { Sarchya } \\
\text { Basic } \\
\text { School }\end{array}$} & FTF & \multirow[b]{2}{*}{ Seventh } & 112 & $91 \%$ \\
\hline & $\begin{array}{l}\text { Distance } \\
\text { learning }\end{array}$ & & 12 & $67 \%$ \\
\hline \multirow{2}{*}{$\begin{array}{c}\text { Kareem } \\
\text { Zand } \\
\text { Basic } \\
\text { School }\end{array}$} & FTF & \multirow[b]{2}{*}{ Seventh } & 60 & $83 \%$ \\
\hline & $\begin{array}{l}\text { Distance } \\
\text { learning }\end{array}$ & & 12 & $67 \%$ \\
\hline \multirow{2}{*}{$\begin{array}{c}\text { Bakrajo } \\
\text { Industrial } \\
\text { High } \\
\text { School }\end{array}$} & FTF & \multirow[b]{2}{*}{ Tenth } & 43 & $81 \%$ \\
\hline & $\begin{array}{l}\text { Distance } \\
\text { learning }\end{array}$ & & 10 & $60 \%$ \\
\hline
\end{tabular}


According to this study, the passing rate of the test performed by the students showed a significant difference between the two methods used to deliver information. As shown in Figure 2 and Figure 3, in FTF teaching method students showed better understanding and achievement compared to distance learning.

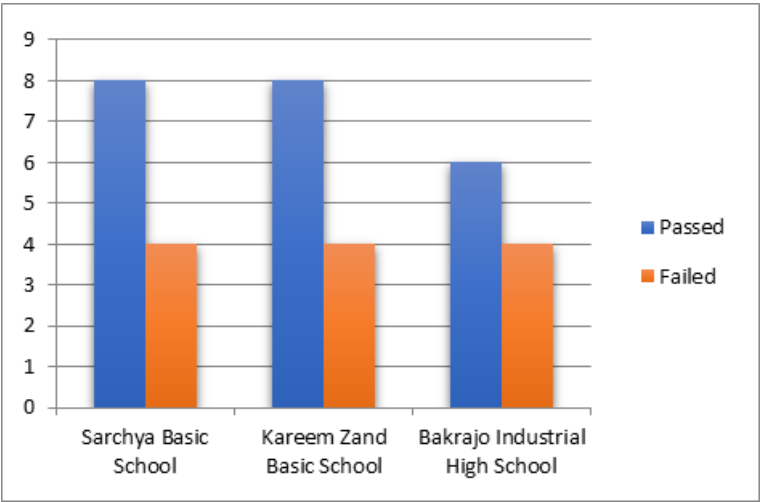

Figure 2: student's test result for FTF teaching method

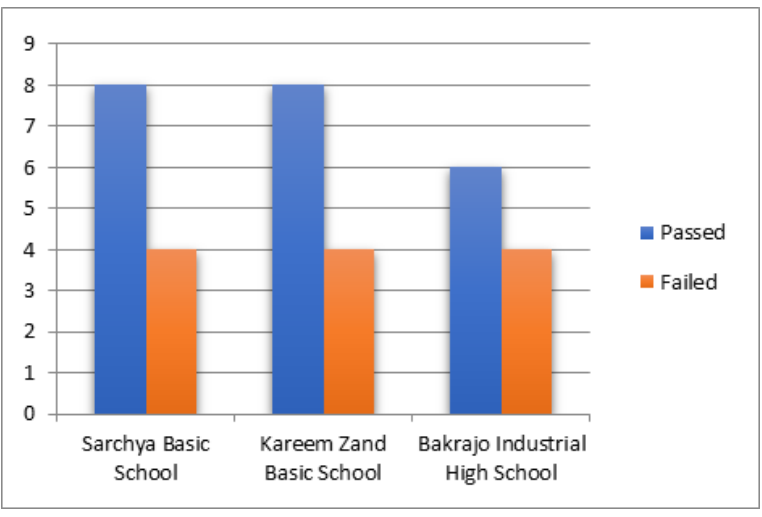

Figure 3: Student's test result for distance teaching method

The aim of this study was to examine students' academic achievement in FTF and distance online method of the same course, accompanied by examining the effects of these two methods on student learning achievement and approval. A total of 232 students involved in this study and the designed course was randomly assigned to either of two methods: one offered FTF instruction, and the other offered online instruction. As shown in this study, the academic achievement of the students recorded better results in FTF method compared to the distance online method as the students showed poorer academic performance in distance online method than FTF method. This finding is contradicted with the findings of the above- mentioned studies (19, 43, 44 and 47) which reported that online course enhances and improve student's performance.

\section{Discussion}

Moreover, this finding is also incompatible with the theory of Russell's study (1990) and also the study of Phillip and Cain (2015) who revealed that there are no significant differences between online courses and FTF method on student's academic performance. The outcome of our study may have been affected by many reasons. For example: online course is a new learning style in Kurdistan region especially for basic school and the students are not familiar with this learning style. Moreover, the internet connection may not be qualified enough for delivering the material to the students therefore, affects the understanding level of the students.

\section{CONCLUSION AND SUGGESTIONS}

The rapid growth of technology affects each sector of the community including education. Distance learning becomes one of the most widely spread forms of delivering information, especially for school programs. Shifting from FTF method to online form of teaching seems to be challenging for both schools' program and instructors. In this paper, we determined 232 students from three schools in Sulaimaniya City. The results showed that most of the students preferred the traditional teaching method in class instead of distance online courses. The passing rate recorded $91 \%$, $83 \%$, and $81 \%$ compared to the passing rate for distance online learning recorded $67 \%, 67 \%$ and $60 \%$ for Sarchya, Kareem Zand and Bakrajo Industrial Schools respectively. This result indicates that using in FTF method is more effective in improving students' academic achievement compared to distance online courses.

Further work is required to determine the factors that affect the students' satisfaction about online courses instead of traditional teaching method and also if the demographic and age factors effect the learning environment of the students. More research is also required to determine if the students' social presence in FTF learning was the reason for their preference for traditional teaching methods. 


\section{REFERENCES}

Ajiboye, A. R., Bakare, M., Fatima, U.-H., \& Shakira, S. (2018). The Impact of Social Network Sites on Knowledge and Information Sharing to Students in the Open Distance Learning Scheme. International Journal of Applied Business and Information Systems, 2(1).

Alavi, M., Yoo, Y., \& Vogel, D. R. (1997). Using information technology to add value to management education. Academy of management Journal, 40(6), 1310-1333.

Allen, I. E., \& Seaman, J. (2016). Online Report Card: Tracking Online Education in the United States. Babson Survey Research Group.

Aragon, S. R., Johnson, S. D., \& Shaik, N. (2002). The influence of learning style preferences on student success in online versus face-to-face environments. The American Journal of Distance Education, 16(4), 227-243.

Barbour, M. (2009). Today's student and virtual schooling: The reality, the challenges, the promise. Journal of Distance Learning, 13(1), 5.

Berge, Z. L. (2005). Virtual schools: Planning for success: Teachers College Press, Columbia Univ.

Bidjerano, T. (2016). online learning in community colleges of the state university of new york: initial results on differences between classroom-only and online learners. Forging new pathways of research and innovation in open and distance learning, 66.

Caetano, F. J., Oliveira, C. M., Araújo, M. F., \& Rêgo, M. C. (2018). Towards Climate Change Awareness Through Distance Learning-Are Young Portuguese and Brazilian University Students Vigilant? In Climate Literacy and Innovations in Climate Change Education (pp. 261273): Springer.

Cavanaugh, J. K., \& Jacquemin, S. J. (2015). A Large Sample Comparison of Grade Based Student Learning Outcomes in Online vs. Face-to-Face Courses. Online Learning, 19(2), n2.

Chimpololo, A. (2010). The prospects and challenges of open learning and distance education in Malawi. World Academy of
Science, Engineering and Technology, 6, 6-29.

Clark, T., \& By, C. (2001). Virtual schools. In.

Collins, J. (2001). Using the Internet as a distance learning tool in selected secondary school areas. Journal of Research on Computing in Education, 33(4), 431-455.

Commission, U. S. W.-b. E., Kerrey, R., \& Isakson, J. (2000). The Power of the Internet for Learning: Moving from Promise to Practice: Report of the Webbased Education Commission: The Commission.

Davis, A. (2017). Project-Based Learning in Distance Learning High School Courses.

Dobrovolny, J., Edwards, D., Friend, B., Harrington, C., Gemin, B., Pape, L., . . . Watson, J. (2015). Keeping Pace with K-12 Digital Learning. An Annual Review of Policy and Practice. Evergreen Education Group.

Estelami, H. (2017). The Pedagogical And Institutional Impact Of Disruptive Innovations In Distance Business Education. American Journal of Business Education (Online), 10(3), 97.

Glenn, A. S. (2001). A Comparison of Distance Learning and Traditional Learning Environments.

Graber, J. (2016). Comparison of face-to-face and distance learning teaching modalities in delivering therapeutic crisis management skills.

Gürsul, F., \& Keser, H. (2009). The effects of online and face to face problem based learning environments in mathematics education on student's academic achievement. Procedia-Social and Behavioral Sciences, 1(1), 2817-2824.

Hachey, A. C., Wladis, C., \& Conway, K. (2015). Prior online course experience and GPA as predictors of subsequent online STEM course outcomes. The Internet and Higher Education, 25, 1117.

Hassel, B. C., Terrell, M. G., \& Impact, P. (2004). How can virtual schools be a vibrant part of meeting the choice provisions of the No Child Left Behind Act. Virtual school report.

Helleve, I. (2012). Differences and similarities in approach between classroom and distance learning. In International 
perspectives of distance learning in higher education: InTech.

Herring, M. C. (2004). Development of constructivist-based distance learning environments: A knowledge base for K12 teachers. Quarterly Review of Distance Education, 5(4), 231.

Johnson, S. D., Aragon, S. R., Shaik, N., \& Palma-Rivas, N. (1999). Comparative Analysis of Online vs. Face-to-Face Instruction.

Leasure, A. R., Davis, L., \& Thievon, S. L. (2000). Comparison of student outcomes and preferences in a traditional vs. world wide web-based baccalaureate nursing research course. Journal of Nursing Education, 39(4), 149-154.

Leszczyński, P., Charuta, A., Łaziuk, B., Gałązkowski, R., Wejnarski, A., Roszak, M., \& Kołodziejczak, B. (2018). Multimedia and interactivity in distance learning of resuscitation guidelines: a randomised controlled trial. Interactive Learning Environments, 26(2), 151-162.

Lewis, S., Whiteside, A., \& Dikkers, A. G. (2014). Autonomy and responsibility: Online learning as a solution for at-risk high school students. Journal of Distance Education (Online), 29(2), 1.

Mathieson, K. (2010). Comparing outcomes between online and face-to-face statistics courses: A systematic review. Paper presented at the Proceedings of the Eighth International Conference on Teaching Statistics. Voorburg, The Netherlands: International Statistics Institute and International Association for Statistical Education. Online: www. stat. auckland. ac. nz/ iase/publications.

McQuaide, S. (2009). Making education equitable in rural China through distance learning. The International Review of Research in Open and Distributed Learning, 10(1).

Mohammed, G. S., Wakil, K., \& Nawroly, S. S. (2018). The Effectiveness of Microlearning to Improve Students' Learning Ability. International Journal of Educational Research Review, 3(3), 32-38.
Moore, M. G., \& Kearsley, G. (2011). Distance education: A systems view of online learning: Cengage Learning.

Nawzad, L., Rahim, D., \& Said, K. W. (2018). The Effectiveness of Technology for Improving the Teaching of Natural Science Subjects. Indonesian Journal of Curriculum and Educational Technology Studies, 6(1), 15-21.

$\mathrm{Ni}$, A. Y. (2013). Comparing the effectiveness of classroom and online learning: Teaching research methods. Journal of Public Affairs Education, 199-215.

Ozdamli, F., \& Uzunboylu, H. (2015). M-learning adequacy and perceptions of students and teachers in secondary schools. British Journal of Educational Technology, 46(1), 159-172.

Ponzurick, T. G., France, K. R., \& Logar, C. M. (2000). Delivering graduate marketing education: An analysis of face-to-face versus distance education. Journal of Marketing education, 22(3), 180-187.

Pratt, K., \& Williamson-Leadley, S. (2017). Effective online learning in New Zealand secondary schools. Paper presented at the Society for Information Technology \& Teacher Education International Conference.

Priluck, R. (2004). Web-assisted courses for business education: An examination of two sections of principles of marketing. Journal of Marketing education, 26(2), 161-173.

SCHOLLEY, S. E. (2001). distance education at the elementary and secondary school levels.

Smeaton, A. F., \& Keogh, G. (1999). An analysis of the use of virtual delivery of undergraduate lectures. Computers \& Education, 32(1), 83-94.

Sultana, S. A., \& Kamal, M. A. (2002). Distance education and open learning in a developing country like Bangladesh: Philosophy and reality. Paper presented at the 2nd Pan-Commonwealth Conference Proceedings.

Taylor, B. D., \& McNair, D. E. (2018). Virtual School Startups: Founder Processes in American K-12 Public Virtual Schools. The International Review of Research in Open and Distributed Learning, 19(1).

Tucker, S. Y. (2000). Assessing the Effectiveness of Distance Education 
8 | Vol 5 No 1, April 2019

versus Traditional On-Campus Education.

Tuckman, B. W. (2002). Evaluating ADAPT: A hybrid instructional model combining web-based and classroom components. Computers \& Education, 39(3), 261269.

Wakil, K., Muhamad, D., Sardar, K., \& Jalal, S. (2017). The Impact of Teaching ICT for Developing Education Systems. Int. J. of Adv. Res, 5, 873-879.

Wakil, K., Nasraddin, R., \& Abdulrahan, R. (2018). The Role of Social Media on Students GPA. Indonesian Journal of Curriculum and Educational Technology Studies, 6(1), 1-5.
Wakil, K., Omer, S., \& Omer, B. (2017). Impact of Computer Games on Students GPA. European Journal of Education Studies.

Wakil, K., Qaisar, N., \& Mohammed, C. (2017). ENRICHING CLASSROOMS WITH TECHNOLOGY IN THE BASIC SCHOOLS. European Journal of Open Education and E-learning Studies.

Watson, J., Murin, A., Vashaw, L., Gemin, B., \& Rapp, C. (2011). Keeping Pace with K-12 Online Learning: An Annual Review of Policy and Practice, 2011. Evergreen Education Group. 